\title{
The reconstruction of the mechanisms of problematic authigenic carbonates formation in diagenetic and catagenetic environments associated with the generation/oxidation of hydrocarbons
}

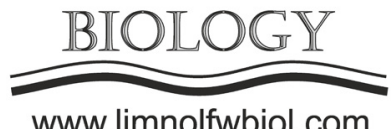

www.limnolfwbiol.com

\author{
Krylov A.A. ${ }^{1,2,3 *}$, Khlystov O.M. ${ }^{2}$, Hachikubo A. ${ }^{4}$, Minami H. ${ }^{4}$, Zemskaya T.I. ${ }^{2}$, \\ Logvina E.A. ${ }^{1}$, Lomakina A.V. ${ }^{2}$, Semenov P.B. ${ }^{1}$ \\ ${ }^{1}$ VNII Okeangeologia, Angliysky pr., 1, St. Petersburg, 190121, Russia \\ ${ }^{2}$ Limnological Institute, Siberian Branch of the Russian Academy of Sciences, Ulan-Batorskaya Str., 3, Irkutsk, 664033, Russia \\ ${ }^{3}$ St.-Petersburg State University, Institute of Earth Sciences, Universitetskaya nab., 7-9, St.-Petersburg, 199034, Russia \\ ${ }^{4}$ Kitami Institute of Technology, 165 Koen-cho, Kitami, 090-8507, Japan
}

\begin{abstract}
Authigenic carbonates are crystallized in subaquatic and subaerial settings at various stages of sedimentary rock formation, and are often found in both ancient and modern deposits. The explanation of their genesis may be problematic. However, in most cases the study of stable isotopes makes it possible to reconstruct the authigenic carbonates crystallization mechanism. The fact of the frequent genetic association of authigenic carbonates with hydrocarbons determines the importance of the development of methods for the reliable identification of their genesis.
\end{abstract}

Keywords: authigenic carbonates, diagenesis, catagenesis, hydrocarbons, methane, Lake Baikal

\section{Introduction}

The following reasons clarify the importance of the authigenic carbonates study: 1) they are sensitive indicators of the crystallization environments; 2) they play a critical role in the global carbon cycle by regulating $\mathrm{CO}_{2}$ balance; 3) carbon dioxide is one of the most effective greenhouse gases that affect global climate change; 4) authigenic carbonates are often associated with hydrocarbons.

The development of reliable methods for reconstructing the authigenic carbonates genesis is one of the most important fundamental scientific problems of sedimentology. Moreover, the determination of the genesis of some carbonates causes great problems (for example, ikaites crystallizing in practically carbonatefree Arctic sediments (Krylov et al., 2015), or siderites of Lake Baikal, anomalously enriched in the heavy ${ }^{13} \mathrm{C}$ isotope (Krylov et al., 2008)). Isotope geochemistry is the most elegant and simple tool used to establish the genesis of carbonates. Oxygen and carbon are the main elements in carbonates, therefore the stable isotopes $\delta^{13} \mathrm{C}$ and $\delta^{18} \mathrm{O}$ are of key importance in genetic reconstructions.

The $\delta^{13} \mathrm{C}$ values are successfully used to clarify the sources of carbon incorporated in the crystal lattice of carbonates. These data make it possible to understand the carbonates main genetic connections: with organic matter, with hydrocarbons or with seawater, i.e. with the main environments responsible for the genesis of most of them. The results of $\delta^{18} \mathrm{O}$ measurements are used to reconstruct the paleotemperature of crystallization and/or the isotopic composition of oxygen in the "water" that surrounds the growth zone ("paleosalinity"). The ambient water can be lacustrine, pore, meteoric, deep fluid, etc, not only marine/oceanic.

Our goal is to use the results of isotopic studies for the reconstruction of the genesis of authigenic carbonates formed under various conditions of diagenesis and catagenesis.

\section{Materials and methods}

Diagenetic carbonates for this study were obtained by the authors in numerous expeditions to various regions: the Arctic shelf, the Sea of Okhotsk, Lake Baikal, the Gulf of Cadiz etc. Catagenetic carbonates were sampled from wells drilled in the zone of distribution of Mesozoic deposits of the Bazhenov formation. Studies of stable isotopes of carbon $\left(\delta^{13} \mathrm{C}\right)$ and oxygen $\left(\delta^{18} \mathrm{O}\right)$ were carried out using a standard method in several laboratories. The $\mathrm{CO}_{2}$ gas was obtained from the completed reaction of the carbonates (1-3 mg) with pure $\mathrm{H}_{3} \mathrm{PO}_{4}$. All carbonate isotope values

*Corresponding author.

E-mail address: akrylow@gmail.com (A.A. Krylov)

(C) Author(s) 2020. This work is distributed under the Creative Commons Attribution 4.0 License. 
are given relative to Vienna Peedee Belemnite (VPDB) scale, using NBS-19 as a standard.

\section{Results and discussion}

According to the results of $\delta^{13} \mathrm{C}$ and $\delta^{18} \mathrm{O}$ measurements, the following genetic groups of carbonates can be confidently distinguished: 1) sedimentagenous ("marine"); 2) diagenetic (2a - due to microbial destruction of organic matter («diagenetic-1»); $2 \mathrm{~b}$ - due to aerobic/anaerobic oxidation of methane of any genetic nature («diagenetic-2»); $2 c$ - due to microbial generation of methane («diagenetic $-3 \ll)$ ); 3 ) «hydrothermal» (oxidation of abiogenic methane); 4) «catagenetic» (destruction of kerogen). Despite some of the above categories are characterized by convergence of isotopic values, we believe that in most cases the carbon source of carbonates can be successfully identified.

The group of sedimentagenous («marine») carbonates includes organogenic (without traces of mechanical treatment), biochemical (for example, stromatolite, oncolitic), chemogenic (formed as a result of crystallization during chemical reactions), detrital (transported before deposition) carbonates. Sea or oceanic water is the source of carbon and oxygen in carbonates of this group. In the first approximation it leads to the closeness of their isotopic $\left(\delta^{13} \mathrm{C}\right.$ and $\left.\delta^{18} \mathrm{O}\right)$ compositions. Isotopic values of most sedimentagenous carbonates will range around $0 \% 0$ ( \pm 3-4 \%o VPDB). As a rule, in carbonates of freshwater lakes, the $\delta^{18} \mathrm{O}$ values will be negative due to the general depletion of freshwaters in the heavy ${ }^{18} \mathrm{O}$ isotope.

Diagenetic carbonates formed due to microbial destruction of organic matter ("diagenetic-1" carbonates) are very widespread in nature. Carbon for carbonates of this type is released in the process of bacterial oxidation of organic matter, mainly through the mediation of the following compounds: $\mathrm{NO}_{3}$, $\mathrm{MnO}_{2}, \mathrm{Fe}_{2} \mathrm{O}_{3}, \mathrm{SO}_{4}{ }^{2-}$. It is believed that during anaerobic oxidation of organic matter (OM) by sulfate-ion (the most common reaction in marine environments), there is practically no isotopic fractionation of carbon (Blair and Aller, 1995); therefore, carbon with an isotopic composition close to the $\delta^{13} \mathrm{C}$ value in $\mathrm{OM}$ is released into the pore water. The $\delta^{13} \mathrm{C}_{\text {org }}$ values vary from -20 to $-30 \%$ VPDB, average -25\%0 VPDB (Galimov, 1999); thus $\delta^{13} \mathrm{C}$ values in "diagenetic-1" carbonates will tend to be of around -25\% VPDB. The $\delta^{18} \mathrm{O}$ values in «diagenetic-1» carbonates are generally close to those in sedimentagenous («marine») carbonates, and vary around $\sim 0 \%$ VPDB ( $\sim$ from -4 to $+5 \%$, depending on temperature and salinity). However, a slight decrease in $\delta^{18} \mathrm{O}$ values with depth is still recorded, since a similar decrease is noted for pore water (Hoefs, 2018).

Carbonates crystallizing due to aerobic/anaerobic oxidation of methane ("diagenetic-2" carbonates) are typical for areas of focused discharge of hydrocarbon fluids (Lein, 2004; Logvina, 2008). Their formation occurs due to the oxidation of methane under anaerobic conditions (or under aerobic conditions in the case of a significant influx of methane). The most common mechanism for increasing alkalinity in pore water is sulfate reduction. Other reactions are also possible, for example, the oxidation of methane by $\mathrm{Fe}$ and/or Mn compounds (Beal et al., 2009). Thus, methanederived carbonates should be enriched in the light ${ }^{12} \mathrm{C}$ isotope and have $\delta^{13} \mathrm{C}$ values lower than $-25 \%$. The $\delta^{18} \mathrm{O}$ values, as a rule, will be close to those in «marine» and «diagenetic-1» carbonates. However, deviations can be observed if there is a significant proportion of mud volcanic fluids, or crystallization of carbonates from the gas hydrates water. In freshwater lacustrine environments, the $\delta^{18} \mathrm{O}$ values will be negative due to the general depletion of fresh waters in the heavy isotope ${ }^{18} \mathrm{O}$ (for example, $\delta^{18} \mathrm{O}$ in the siderites of Lake Baikal varies from -9.9 to $-13.9 \%$ VPDB (Krylov et al., 2008)).

It should be borne in mind that the mechanisms responsible for the crystallization of "diagenetic-1" and "diagenetic-2" carbonates can act simultaneously. In this case, carbon enters the crystal lattice of carbonates from several sources. The proportion of carbon from different sources can be calculated, as, for example, for the ikaites of the Laptev Sea (Krylov et al., 2015).

The mechanism of carbonate formation due to the generation of methane (and $\mathrm{CO}_{2}$ ) by archaea during the diagenetic destruction of OM ("diagenetic-3" carbonates) is currently poorly understood. The results of the previous studies suggest the formation of authigenic siderites from sediments of Lake Baikal occurs precisely due to this mechanism (Krylov et al., 2008). The general reaction can be conventionally written down as follows: $2 \mathrm{CH}_{2} \mathrm{O} \rightarrow \mathrm{CO}_{2}+\mathrm{CH}_{4}$. The main feature of the isotopic composition of carbonates is the enrichment with heavy ${ }^{13} \mathrm{C}$ isotope and consequently positive $\delta^{13} \mathrm{C}$ values. The reason for this is the predominant concentration of the isotope ${ }^{12} \mathrm{C}$ in methane, and ${ }^{13} \mathrm{C}$ in carbon dioxide. As a rule, $\delta^{13} \mathrm{C}$ values exceed $+5 \%$ and can reach values of $+36 \%$. It is interesting that unlike other regions the finds of siderite extremely enriched in the heavy ${ }^{13} \mathrm{C}$ isotope, are located very close to the Lake Baikal bottom. The $\delta^{18} \mathrm{O}$ values are generally similar to those of the «diagenetic-2» carbonates.

The formation of carbonates in catagenesis occurs due to the destruction of kerogen under the conditions of elevated temperatures and pressures. The generation of $\mathrm{CO}_{2}$ from kerogen begins almost simultaneously with the formation of oil at a temperature of about $50^{\circ} \mathrm{C}$ and decreases in the zone of the maximum of the «oil window» corresponding to a temperature of $100-110^{\circ} \mathrm{C}$ (Seewald, 2003). The conversion of carbon dioxide into bicarbonate ion, causing an increase in $\mathrm{pH}$, occurs due to the reaction with aluminosilicates (more often - feldspars) (a similar mechanism works for "diagenetic-3" carbonates) (Lebedev, 1992; Wallmann et al., 2008). The presence of both a relatively light carbon isotopic composition $\left(\delta^{13} \mathrm{C} \sim\right.$ from -15 to -25 $\%$ VPDB) and a light oxygen composition confirms the crystallization of carbonates from kerogen, since the formation of carbonates at elevated temperatures leads to the concentration of ${ }^{16} \mathrm{O}$ isotopes in the crystal lattice. 


\section{Conclusion}

Based on $\delta^{13} \mathrm{C}$ and $\delta^{18} \mathrm{O}$ data, the following groups of carbonates can be confidently distinguished: 1 sedimentagenous ("marine"); 2 - diagenetic (2a - due to microbial destruction of organic matter («diagenetic-1»); $2 \mathrm{~b}$ - due to aerobic / anaerobic oxidation of methane of any genetic nature («diagenetic-2»); $2 \mathrm{c}$ - due to microbial generation of methane («diagenetic-3 «)); 3) «hydrothermal» (oxidation of abiogenic methane); 4) «catagenetic» (destruction of kerogen). As follows from the above classification, most types of authigenic carbonates are associated with the oxidation or generation of hydrocarbons. This fact determines the importance of studying the carbonates.

\section{Acknowledgments}

This work was supported by the grant RNF-19-17-00226.

\section{References}

Beal E.J., House C.H., Orphan V.J. 2009. Manganeseand iron- dependent marine methane oxidation. Science 325(5937): 184-187. DOI: 10.1126/science.1169984

Blair N.E., Aller R.C. 1995. Anaerobic methane oxidation on the Amazon shelf. Geochimica et Cosmochimica Acta 59(18): 3707-3715. DOI: 10.1016/0016-7037(95)00277-7

Galimov E.M. 1999. The causes of the global variations of carbon isotopic composition in the biosphere. Geochemistry International 37(8): 699-713.

\section{Hoefs J. 2018. Stable isotope geochemistry. $8^{\text {th }} \quad$ ed. Berlin/Heidelberg: Springer-Verlag. DOI: 10.1007/978-3-540-70708-0}

Krylov A., Khlystov O., Zemskaya T. et al. 2008. First discovery and formation process of authigenic siderite from gas hydrate-bearing mud volcanoes in fresh water: Lake Baikal, Eastern Siberia. Geophysical Research Letters 35. DOI: 10.1029/2007GL032917

Krylov A.A., Logvina E.A., Matveeva T.V. et al. 2015. Ikaite $\left(\mathrm{CaCO}_{3} \cdot 6 \mathrm{H}_{2} \mathrm{O}\right)$ in bottom sediments of the Laptev Sea and the role of anaerobic methane oxidation in this mineralforming process. Zapiski RMO [Transactions of the Russian Mineralogical Society] 4: 61-75. (in Russian)

Lebedev B.A. 1992. Geokhimiya epigeneticheskikh protsessov $\mathrm{v}$ osadochnykh basseynakh [Geochemistry of epigenetic processes in sedimentary basins]. Leningrad: Nedra. (in Russian)

Lein A.Yu. 2004. Authigenic carbonate formation in the Ocean. Lithology and Mineral Resources 39(1): 1-30. DOI: 10.1023/B:LIMI.0000010767.52720.8f

Logvina E.A. 2008. Different scripts of authigenic mineral formation in the fluid discharge structure-sediments. Vestnik Sankt-Peterburgskogo Universiteta. Seriya 7. Geologiya. Geografiya [Bulletin of St.-Petersburg University. Series 7. Geology. Geography] 4: 46-61. (in Russian)

Seewald J.S. 2003. Organic-inorganic interactions in petroleum-producing sedimentary basins. Nature 426: 327-333. DOI: 10.1038 /nature02132

Wallmann K., Aloisi G., Haeckel M. et al. 2008. Silicate weathering in anoxic marine sediments. Geochimica et Cosmochimica Acta 72: 3067-3090. DOI: 10.1016/j. gca.2008.03.026 